\title{
An advanced stage of ankle arthropathy in a haemophilic patient
}

\author{
Ali Kemal Sivrioglu, ${ }_{1}^{1}$ Selahattin Ozyurek, ${ }^{2}$ Muzaffer Saglam, ${ }^{3}$ Guner Sonmez ${ }^{3}$
}

${ }^{1}$ Department of Radiology, Aksaz Military Hospital,

Mugla, Turkey

${ }^{2}$ Department of Orthopedic Surgery, Aksaz Military Hospital, Mugla, Turkey

${ }^{3}$ Department of Radiology, GATA Haydarpasa Teaching Hospital, Istanbul, Turkey

Correspondence to Dr Ali Kemal Sivrioglu, draksivrioglu@gmail.com
To cite: Sivrioglu AK, Ozyurek S, Saglam M, et al. BMJ Case Rep Published online: [please include Day Month Year] doi:10.1136/ bcr-2013-009038

\section{DESCRIPTION}

A 17-year-old boy with Haemophilia A was referred to an orthopaedic surgeon with pain and swelling in the right ankle. His medical history included incidents of right ankle trauma. On physical examination, there was swelling and increasing tenderness in the right ankle with movement. Moderate limitation of motion in the right ankle was also observed. The plasma levels of factor VIII were within 50\% of normal. It was consistent with mild Haemophilia A. On direct radiographs, narrowing, sclerosis and irregularities of joint surfaces were observed in the subtalar joint. On sagittal T1 and T2-weighted MRI, narrowing, irregularity and subchondral cysts were observed in the middle and posterior of the subtalar joint (figure 1). Sagittal and coronal T2-weighted images showed bone marrow oedema of the talus and calcaneus, and joint surfaces of the subtalar joint (figure 2). Moreover, loss of articular cartilage and mild hypointensity compatible with the accumulation of haemosiderin were seen on the subtalar joint surfaces on T2-weighted images. The right tibiotalar joint was normal. These findings were consistent with haemophilic arthropathy. The patient's complaints decreased with physical therapy and surgical synovectomy.

Haemophilia A is the most common hereditary bleeding disorder. Haemarthrosis is the most common finding of haemophilia in the musculoskeletal system. Blood in the joint can directly damage the cartilage. ${ }^{1}$ In addition, there is progressive destruction of both cartilage and bone with repeated bleeding. The knees, elbows and ankles are the most commonly affected joints. In the ankle, both the tibiotalar and subtalar joints may be affected and arthropathy can lead to a number of deformities. ${ }^{2}$

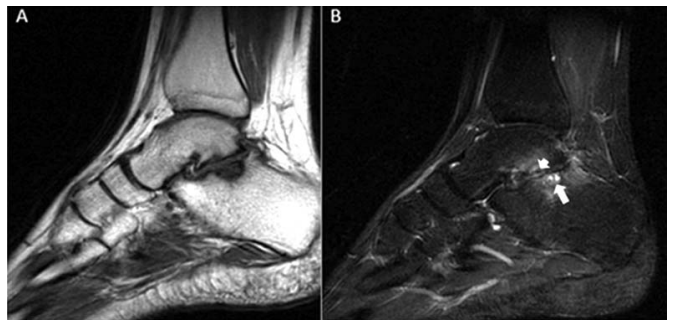

Figure 1 A 17-year-old boy with haemophilia A. On sagittal T1 (A)- and T2 (B)-weighted MRI, narrowing, irregularity and subchondral cysts (arrow) are observed in middle and posterior subtalar articular surfaces of talus and calcaneus. In addition, mild hypointensity (arrowhead) compatible with the accumulation of haemosiderin on each image is seen on the subtalar joint surfaces.

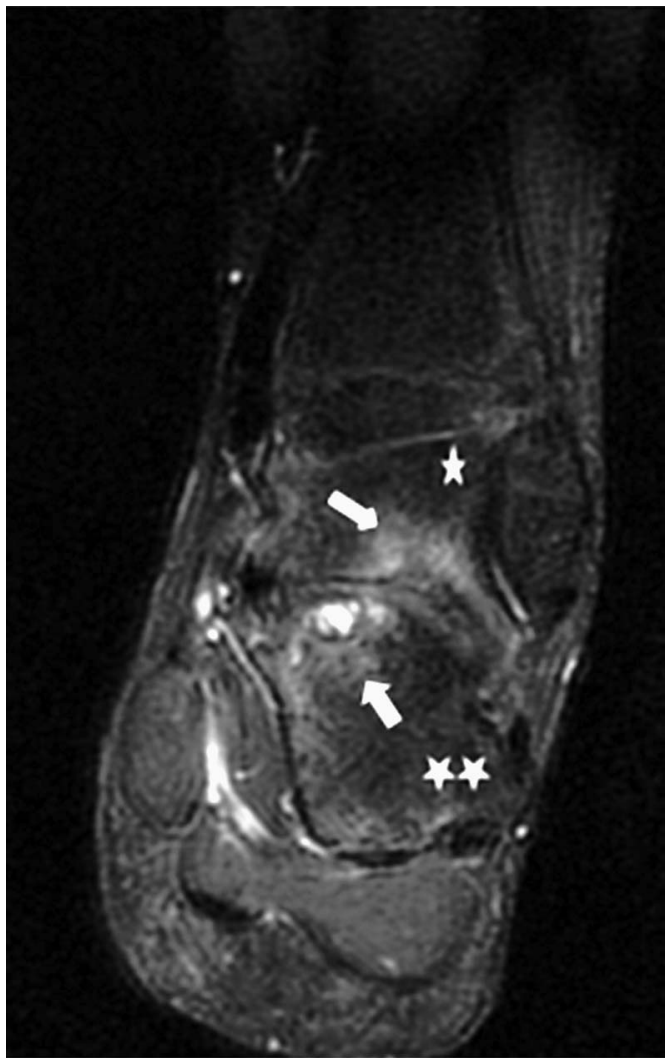

Figure 2 Coronal T2-weighted images show bone marrow oedema (arrows) of the subtalar articular surfaces of talus $\left({ }^{*}\right)$ and calcaneus $\left(^{* *}\right)$.

\section{Learning points}

- Haemarthrosis is the most common finding of Haemophilia in the musculoskeletal system. The knees, elbows and ankles are the most commonly affected joints.

- Haemophilic arthropathy leads to progressive destruction of both cartilage and bone because of repeated bleeding.

Competing interests None.

Patient consent Obtained.

Provenance and peer review Not commissioned; externally peer reviewed.

\section{REFERENCES}

1 Jansen NW, Roosendaal G, Bijlsma JW, et al. Exposure of human cartilage tissue to low concentrations of blood for a short period of time leads to prolonged cartilage damage. Arthritis Rheum 2007:56:199-207.

2 Pasta G, Orsyth A, Merchan CR, et al. Orthopaedic management of haemophilic arthropathy of the ankle. Haemophilia 2008:14:170-6. 


\section{Images in...}

Copyright 2013 BMJ Publishing Group. All rights reserved. For permission to reuse any of this content visit http://group.bmj.com/group/rights-licensing/permissions.

BMJ Case Report Fellows may re-use this article for personal use and teaching without any further permission.

Become a Fellow of BMJ Case Reports today and you can:

- Submit as many cases as you like

- Enjoy fast sympathetic peer review and rapid publication of accepted articles

- Access all the published articles

- Re-use any of the published material for personal use and teaching without further permission

For information on Institutional Fellowships contact consortiasales@bmjgroup.com

Visit casereports.bmj.com for more articles like this and to become a Fellow 